\title{
CONSTRAINTS ON ACQUISITION OF ELECTRICAL INSTALLATION AND MAINTENANCE WORK SKILLS AMONG STUDENTS IN TECHNICAL COLLEGES IN AKWA-IBOM STATE
}

\author{
Prof. Soubere T. Puyate, Edem, Unyime Joseph \\ Department of Vocational and Technology Education, \\ Rivers State University, Port Harcourt, Rivers State, (Nigeria) \\ E-mail: revpuyatest@yahoo.com, ujedem2018@ gmail.com
}

\begin{abstract}
The study sought to find out Constraints on Acquisition of Electrical Installation and Maintenance Work Skills Among Students in Technical colleges in Akwa-Ibom State,. Descriptive survey design was used in the design of the study. The population of the study consisted of a total of 332 respondents comprising 286 final year vocational III students and 46 teachers of VOCIII students from the five (5) government technical colleges in Akwa Ibom State. Simple random sampling technique was employed in the selections. For the teachers, all the 46 of the VOCIII teachers were used. A structured questionnaire titled 'Constraints on Acquisition of Electrical Installation and Maintenance Work Skills Questionnaire was developed to elicit responses from the respondents after being validated by the supervisor and three other experts and reliability tested through the use of Pearson Product Moment Correlation Method to obtain an average reliability coefficient of 0.86. Mean was adopted for answering the research questions. The hypotheses were tested using z-test statistics. The result revealed that some of the factors that constitute as constraints on acquisition of electrical installation and maintenance work skills among students in technical colleges in Akwa Ibom State include: teaching methodology, and students' associated factors. Based on the findings, it was recommended that special agency should be established for training and retraining of technical teachers and government should establish Agency for Attitudinal Change for technical colleges to take charge of students' performance award, motivation, discipline and encouragement of in all the technical colleges.
\end{abstract}

KEYWORDS: electrical installation, maintenance, work skills, students, technical colleges, Akwa-Ibom State

\section{INTRODUCTION}

That there are needs for manpower development in electrical installations and maintenance works for economic growth of any nation and overall benefit of man is an indisputable fact. This development according to Puyate (2018) cannot be possible without practitioners in the field of Technical and Vocational Education and Training (TVET) paying special attention to practical skills acquisition. The acquisition of workplace skills is seen globally as a cardinal driver of economic and technological development (Jane, Raymond \& Patrick, 2017).

In a developing country like Nigeria, the importance and relevance of technical and vocational education and training cannot be overemphasized (Okwelle \& Ojotule, 2018). According to Imogie (2014), no nation can develop to its fullest and keep pace with trends in science and technology without effective and efficient technical and vocational education and training 
system. TVET equips people with a broad range of knowledge, skills and attitudes that are now recognized as indispensable in meaningful participation in work and life (Okwelle, 2013).

Idoko (2014) explains acquisition of practical skills to involve the development of new skills, practice and performing a task, usually gained through training experience. According to Okwelle and Ojotule (2018) practical skills acquisition could be referred to as an organized process of training which eventually leads to the effectiveness of an individual in a given trade. The National Policy on Education (NPE) explained that, "technical vocational education is used as a comprehensive term referring to those aspects of the educational process and training involving in addition to general education, the study of technologies and related sciences and the acquisition of practical skills, attitudes, understanding and knowledge relating to occupations in various sectors of economic and social life" (FGN, 2004:30).

As posited by Okoye and Okwelle (2013), TVET is a system of education that prepares, develops and practically orientates the individual for the purpose of transforming idea into reality. In Nigerian educational system, technical colleges offer technical and vocational education programmes for the purpose of producing middle level skilled manpower needed for the nation's national economic and technological development (FGN, 2013).

The Nigerian National Policy on Education (2013) outlines the goals of TVET as follows:

i. $\quad$ To provide trained man-power in applied sciences, technology and business.

ii. To provide technical knowledge and vocational skills necessary for economic development.

iii. To give training and impart necessary skill for self-reliance economically.

It is clearly seen from the goals outlined above that TVET is an effective, positive catalyst for achieving sustainable economic development and prosperity in a state like Akwa Ibom through economic emancipation of individual citizenry of Akwa Ibom State in particular, Nigeria and beyond in general.

According to Puyate (2018), Technical and Vocational Education and Training would be described as:

i. An integral part of general education

ii. A means of preparing for occupational fields and effective participation in the world of work.

iii. An aspect of lifelong learning and preparation for responsible citizenship

iv. An instrument for promoting environmentally sound sustainable development; and

v. A positive means of alleviating poverty.

\section{Statement of the Problem}

The increasing dearth of competent skilled artisans in different fields of technology is becoming worrisome issue today. The country is now at the point of importing foreign labour from all over the world due to lack of competent Nigerians with adequate practical skills for the demand of the economy and the labour market. A number of researchers; Akaninwor (2008), Puyate (2018), Puyate (2012), Okwelle and Normakoh (2019), Okwelle and Ojotule 
(2018), Okwelle, Beako and Ajie (2017), Amadi and Nnodim (2018), particularly in technical and vocational education have attributed lack of practical skills of the technical college graduates to some issues of constraints on the process of teaching and learning in the institutions. Puyate (2008), Odu (2011), Ayomike (2014) and Igberadja (2013) among others also reported similar views.

Technical Colleges were established over the years for the training of technicians and in the various trades. Why is it that up till now, there is the dearth need of skilled manpower in Nigeria? This study was designed in part to find out.

\section{Purpose of the Study}

The main purpose of the study is to investigate the constraints to acquisition of Electrical Installations and Maintenance Works Skills among Students in technical colleges in Akwa Ibom State. Specifically, the study was to:

1. Determine what teaching methodology factors constitute as constrain to Acquisition of Electrical Installation and Maintenance Work Skills Among Students in technical colleges in Akwa Ibom State.

2. Determine what students' associated factors constitute as constrain to acquisition of Electrical Installation and Maintenance Work Skills Among Students in Technical colleges in Akwa-Ibom State.

\section{Research Questions}

The following research questions are raised to guide the study:

1. What constraints do teaching methodology constitute on acquisition of Electrical Installation and Maintenance Work skills among students in technical colleges in AkwaIbom State?

2. What constraints do students' associated factors constitute on acquisition of Electrical Installation and Maintenance Work skills among students in technical colleges in AkwaIbom State?

\section{Hypotheses}

The following null hypotheses were postulated for the study:

H01: There is no significant difference in the mean responses of students and teachers on teaching methodology constituting as constraints on Acquisition of Electrical Installation and Maintenance Work Skills Among Students in Technical colleges in Akwa-Ibom State.

H03: There is no significant difference in the mean responses of students and teachers on students' associated factors constituting constraints on Acquisition of Electrical Installation and Maintenance Work Skills Among Students in Technical Colleges in Akwa-Ibom State. 


\section{Significance of the Study}

Taking cognizance of students', government's, companies' and the general society's concern over the glaring production of ineffective, insufficient and inefficient middle manpower in technical colleges, a study which tends to bring into limelight the factors constraining acquisition of Electrical Installations and Maintenance Works Skills among Students in technical colleges in Akwa Ibom State, occupies prominent status. However, the following persons hopefully, will benefit from the study in the following ways:

The students will benefit from the result of the study if positive change in attitude and appropriate teaching methodology are adopted by the technical students and teachers in the colleges. Also, the teachers will consider the study useful if they adopt effective teaching methodology on the various vocations and technical subjects. The Akwa Ibom State government in particular and the general society will benefit from the study because it can lead to effective and efficient production of middle man-power to drive technological growth and development. Researchers will consider the study useful owing to the expected experiences that will be derived from it as a result of ideals that will be unfolded. Finally, the National Board for Technical Education Board, will serve as a springboard from where other ideas can emanate.

\section{Scope of the Study}

Scope being the body of knowledge the study will cover the following aspects only: teaching methodology and students' associated factors. The study is concerned with the investigation of some constraints that students of technical colleges in Akwa Ibom State encounter in acquiring practical skills in Electrical Installation and Maintenance Work.

\section{METHODOLOGY}

Descriptive survey design was adopted in this study. The study was conducted in five technical colleges in Akwa Ibom State of Nigeria.

The population of the study comprised 332 respondents which consisted of 286 final year (VOC III) students who offered the trade and 46 teachers of VOC. III from the five (5) Government Technical Colleges in the State. A Sample of 244 respondents comprising 198 students representing $69 \%$ of the students' population and 46 teachers were sampled randomly from a total population of 332 respondents for the study. Questionnaire was used by the researcher. The questionnaire comprises five (5) sections, namely, A, B, C, D and E. Section A obtained information on the personal characteristics of the respondents. Section B obtained information on the teaching methodology factors. Section C obtained information on workshop facilities factors in the technical colleges. Section D obtained information on the students' associated factors in the technical colleges and Section E obtained information on the funding connected factors in the technical colleges. The 40 item structured questionnaire was a closed ended type. The questionnaire was structured based on a 4-point rating scale of Strongly Agree $(\mathrm{SA}=4)$, Agree $(\mathrm{A}=3)$, Disagree $(\mathrm{D}=2)$, and Strongly Disagree $(\mathrm{SD}=1)$. 


\section{Validity of the Instrument}

To determine the validity of the instrument, the questionnaire was scrutinized by the researcher's supervisor and three other experts in the Department of Vocational and Technology Education. Their comments and corrections were added to form the final instrument for the study.

\section{Reliability of the Instrument}

In order to determine the reliability of the instrument, two (2) pilot tests of the instrument were carried out with thirty three respondents selected from two technical colleges in Abia State with values 0.85 and 0.86. Pearson Product Moment Correlation was used to ascertain the reliability of the instrument. The average reliability coefficient value of 0.86 obtained was considered adequate for the study.

\section{Administration of the Instrument}

The researcher personally administered the questionnaires with the help of a research assistant daily in each of the schools to the sample groups. The completed questionnaire copies were retrieved from the respondents the same day. This was to ensure maximum response rate.

\section{Method of Data Analysis}

The data collected were analyzed using mean scores while the null hypotheses were tested with z-test statistics at 0.05 level of significance, to either accept if the mean value is up to and above 2.50 or reject if the mean value is 2.49 , constraints on acquisition of electrical installation and maintenance work skills among students in technical colleges in Akwa Ibom State. Acceptance and rejection of the null hypothesis was based on the calculated $\mathrm{z}$-cal; if the calculated $\mathrm{t}(\mathrm{z}-\mathrm{cal})$ was greater than or equal to the critical or table value, the null hypothesis was rejected in favour of the alternative hypothesis and if the calculated $\mathrm{t}(\mathrm{z}$-cal) was less than the critical or table value the null hypothesis was accepted in disfavour of the alternative hypothesis.

\section{Data Analysis and Results}

\section{Research Question 1}

What constraints does teaching methodology constitute on acquisition of Electrical Installation and Maintenance Work skills among students in technical colleges in Akwa-Ibom State?

Data for answering research questions one were collected and analyzed. They are presented in table 1. 
Table 1: Mean Responses of Students and Teachers on teaching methodology that constraining Acquisition of Electrical Installations and Maintenance Works Skills.

\begin{tabular}{|c|c|c|c|c|c|c|c|}
\hline \multirow[t]{2}{*}{$\mathbf{S} / \mathbf{N}$} & \multirow[t]{2}{*}{ Items } & \multicolumn{3}{|c|}{ Students } & \multicolumn{2}{|c|}{ Teachers } & \multirow[b]{2}{*}{ Remark } \\
\hline & & $\bar{X}$ & SD & Remark & $\bar{X}$ & SD & \\
\hline 1 & Demonstration method & 2.85 & 1.19 & $\mathrm{~A}$ & 2.87 & 1.20 & $\mathrm{~A}$ \\
\hline 2 & Lecturing method & 2.93 & 1.10 & $\mathrm{~A}$ & 2.91 & 1.11 & A \\
\hline 3 & Workshop based teaching method & 3.13 & 0.89 & A & 3.09 & 0.94 & A \\
\hline 4 & Excursion and field trip method & 2.95 & 0.95 & A & 2.91 & 0.98 & A \\
\hline 5 & Problem based teaching method & 2.93 & 1.09 & A & 2.96 & 1.09 & A \\
\hline 6 & Seminar method & 3.11 & 0.89 & A & 3.11 & 0.92 & A \\
\hline 7 & Context based teaching method & 2.41 & 1.17 & $\mathrm{D}$ & 2.93 & 1.16 & A \\
\hline 8 & Simulation method & 2.74 & 1.04 & A & 2.78 & 1.03 & A \\
\hline 9 & Project based teaching method & 2.86 & 1.08 & A & 2.83 & 1.12 & A \\
\hline \multirow[t]{2}{*}{10.} & Discussion method & 1.90 & 0.99 & $\mathrm{D}$ & 1.87 & 0.98 & $\mathrm{D}$ \\
\hline & Grand Mean and Standard deviation & 2.78 & 1.04 & & 2.83 & 1.05 & \\
\hline
\end{tabular}

Source: Field Survey, $2019 \quad$ Key: A = Agree, D = Disagree

Table 1 shows the mean responses of students and teachers on teaching methodology related factors that constrained acquisition of Electrical Installation and Maintenance Work Skills in technical colleges in Akwa Ibom State. As indicated in the above table, the respondents agreed to all the statements except item 10 as constraints to electrical installation and maintenance works skills with mean responses greater than 2.50 for both students and teachers respectively. However, while students disagreed on item 7 , teachers were divergent. On the whole, the grand mean of 2.78 and 2.83 for both students and teachers are obvious indications that there are teaching methodology related factors that constrained acquisition of Electrical Installations and Maintenance Works skills among students in technical colleges in Akwa Ibom State.

\section{Research Question 2}

What constraints do students' associated factors constitute on acquisition of Electrical Installation and Maintenance Work skills among students in technical colleges in Akwa-Ibom State?

Data for answering research question two were collected and analyzed. It is presented in table 2. 
Table 2: $\quad$ Mean Responses of Students and Teachers on Students' Associated Factors that Constrained Acquisition of Electrical Installations and Maintenance Works Skills.

\begin{tabular}{llcccccc}
\hline S/N & Items & \multicolumn{3}{c}{ Students } & \multicolumn{2}{c}{ Teachers } \\
& & $\bar{X}$ & SD & Remark & $\bar{X}$ & SD & Remark \\
\hline 21 & Lateness to practicals. & 2.80 & 1.07 & $\mathrm{~A}$ & 2.83 & 1.06 & $\mathrm{~A}$ \\
22 & Irregular attendance. & 2.96 & 1.04 & $\mathrm{~A}$ & 3.00 & 1.06 & $\mathrm{~A}$ \\
23 & Lack of cooperation. & 2.70 & 1.06 & $\mathrm{~A}$ & 2.67 & 1.10 & $\mathrm{~A}$ \\
24 & Lack of participation in excursion. & 2.07 & 1.05 & $\mathrm{D}$ & 2.07 & 1.04 & $\mathrm{D}$ \\
25 & Refusal for SIWES participation. & 2.06 & 1.07 & $\mathrm{D}$ & 2.04 & 1.07 & $\mathrm{D}$ \\
26 & Preference of theory over practicals & 2.24 & 1.12 & $\mathrm{D}$ & 2.22 & 1.11 & $\mathrm{D}$ \\
27 & Students' laziness. & 2.68 & 0.95 & $\mathrm{~A}$ & 2.70 & 0.92 & $\mathrm{~A}$ \\
28 & Students' nonchalant attitude. & 2.68 & 0.96 & $\mathrm{~A}$ & 2.67 & 0.64 & $\mathrm{~A}$ \\
29 & Lack of hard work spirit. & 3.03 & 0.88 & $\mathrm{~A}$ & 2.96 & 1.03 & $\mathrm{~A}$ \\
30 & Lack of interest in practical & 2.30 & 1.09 & $\mathrm{D}$ & 2.30 & 1.11 & $\mathrm{D}$ \\
& assignments. & & & & & & \\
& & $\mathbf{2 . 5 5}$ & $\mathbf{1 . 0 3}$ & & $\mathbf{2 . 5 5}$ & $\mathbf{1 . 0 1}$ & \\
& Grand Mean & & & & & & \\
\hline
\end{tabular}

Source: Field Survey, $2019 \quad$ Key: A = Agreed, D = Disagreed

The data presented on table 2 represents the mean responses of students and teachers on students' associated factors with constraints on students' acquisition of Electrical Installation and Maintenance Work among students in technical colleges in Akwa Ibom State. As shown in the above table, all the respondents agreed to the statements on items 21, 22, 23, 27, 28 and 29 as significant constraints on Acquisition of Electrical Installation and Maintenance Work among students in all the government approved technical colleges in Akwa Ibom State as evident in the mean responses greater than 2.50. However they disagreed with the statements on items 24, 25, 26 and 30 whose mean responses are less than 2.50. On the whole, the grand mean of 2.55 for both students and teachers shows a general agreement of existence of students' associated factors that constrained acquisition of Electrical Installations and Maintenance Work among students in technical colleges in Akwa Ibom State.

\section{Hypotheses Testing Hypothesis 1}

There is no significant difference in the mean responses of students and teachers on whether teaching methodology constitutes as constraints on acquisition of Electrical Installation and Maintenance Work Skills among students in technical colleges in Akwa Ibom State.

Data for providing test to hypothesis one $\left(\mathrm{Ho}_{1}\right)$ were analyzed and presented in table 3. 
British Journal of Education

Vol.8, Issue 4, pp.46-56, April 2020

Published by ECRTD- UK

Print ISSN: ISSN 2054-6351

Online ISSN: ISSN 2054-636X

Table 3: $\quad$ z-test on Teaching Methodology Related Factors

\begin{tabular}{lccccccc}
\hline Groups & $\bar{X}$ & SD & N & df & zcal & z crit. & Decision \\
\hline Students & 2.78 & 1.04 & 198 & & & & \\
Teachers & 2.83 & 1.05 & 46 & & & & Accept \\
\hline
\end{tabular}

Source: Field Survey, 2019

Results from Table 3 show the difference in the mean responses of students and teachers on the Teaching Methodology related factors constituting constraints to acquisition of Electrical Installation and Maintenance Work skills among students in technical colleges in Akwa Ibom State.

Hypothesis test of significant difference yielded Zcal. value of 0.29 against Zcrit. value of 1.96 . Since the Zcal was less than the Zcrit the hypothesis was accepted. This implies that students' mean response did not significantly differ from teachers' mean response regarding Teaching Methodology related factors constituting constraints to acquisition of Electrical Installation and Maintenance Work skills. This is in line with the results shown in Table 4.1 with similar mean values between students and teachers.

\section{Hypothesis 2}

There is no significant difference in the mean responses of students and teachers on whether students' associated factors constitute as constraints on Acquisition of Electrical Installation and Maintenance Work Skills Among Students in Technical colleges in Akwa-Ibom State.

Data for providing test to hypothesis 3 were analyzed and presented in Table 4.

Table 4: $\quad$ z-test on Students' Associated Factors

\begin{tabular}{lccccccc}
\hline Groups & $\bar{X}$ & SD & N & df & $\mathbf{Z}$ cal & Crit. & Decision \\
\hline Students & 2.55 & 1.03 & 198 & 242 & 0.00 & 1.96 & Accept \\
Teachers & 2.55 & 1.01 & 46 & & & & \\
\hline
\end{tabular}

Source: Field Survey, 2019

Results from Table 4 show the difference in the mean responses of students and teachers on whether the students' associated factors constitute as Constraints on Acquisition of Electrical Installation and Maintenance Work Skills Among Students in Technical colleges in AkwaIbom State. Hypothesis test of significant difference yielded Zcal. value of 0.00 against Zcrit. value of 1.96.Since the Zcal was less than the Zcrit. the hypothesis was accepted. This implies that students' mean response did not significantly differ from teachers' mean response on whether students' associated factors constituting Constraints on Acquisition of Electrical Installation and Maintenance Work skills Among Students in Technical colleges in AkwaIbom State. This is in agreement with the results in table 4.3 with the similar mean values for both students and teachers respectively. 


\section{DISCUSSION OF FINDINGS}

Research question one (1) intended to find out how teaching methodology related factors constrained acquisition of Electrical Installation and Maintenance Work Skills in the five (5) technical colleges in Akwa Ibom State. The results from the analysis revealed that many teachers never used the proper teaching methodology as necessary for students' acquisition of Electrical Installation and Maintenance Work Skills in the technical colleges. Though item 10 indicated that most of the technical teachers in technical colleges in Akwa Ibom State devote their time to discuss adequately during practical classes with students, the grand means of 2.78 and 2.83 for students and teachers indicate teaching methodology constrained acquisition of Electrical Installation and Maintenance Work Skills among students in technical colleges in Akwa Ibom State.

The hypothesis test of significant difference in the mean responses of students and teachers regarding teaching methodology related factors in technical colleges in Akwa Ibom State buttresses the results obtained on Table 4 as the calculated value of $Z(0.29)$ was less than the $\mathrm{Z}$ critical value (1.96).

This finding is in consonance with Ochogba, Ogide and Ogide (2019) who discovered that most technical trade teachers do not use suitable methods in teaching practical skill trades. The result is also in agreement with Ogide (2017) who found out that the reason for students' poor performance in technology related trades is sequel to the teaching method adopted by their teachers.

Research question two (2) sought to ascertain the influence of students' associated factors that Constrained Acquisition of Electrical Installation and Maintenance Work Skills among Students in Technical colleges in Akwa-Ibom State. The result shows that the respondents agreed that lateness of students to practical classes, irregular attendance to practical, lack of students' cooperation with their technical trades teachers, students' laziness, students' nonchalant attitude, lack of hard work spirit and lack of interest in practical assignments as Constraints on Acquisition of Electrical Installation and Maintenance Work Skills Among Students in Technical colleges in Akwa-Ibom State. On the whole, the grand mean of 2.55 for both students and teachers indicate students' associated constraints on acquisition of Electrical Installation and Maintenance Work among students in the technical colleges in the State.

The hypothesis test of significant difference in the mean responses of the respondents on students' associated factors that Constrained acquisition of Electrical Installation and Maintenance Work Skills among Students in Technical colleges in Akwa-Ibom State is in consonance with the results obtained in table 4 with the Zcal. (0.04) less than Zcrit. (1.96) values respectively. This result affirms the study carried out by Oguniyi (2015), Ngogo (2014), Elias, Smith and Barney (2012) who found out that learners' attitudes affect the level of acquisition of practical skill by students of technical colleges and the likes.

\section{CONCLUSION}

The study sought to investigate the constraints on acquisition of Electrical Installation and Maintenance Work Skills among students in technical colleges in Akwa-Ibom State. From the data analysis and findings, it can be conclusively said that technical trade teachers in technical 
colleges in Akwa Ibom State do not always adopt the most suitable teaching methodology. Consequently, this has contributed adversely to students' acquisition of Electrical Installation and Maintenance Work Skills on graduation from the colleges in the State. In the study also, deficiency in acquisition of Electrical Installation and Maintenance Work Skills in technical colleges in Akwa Ibom State has been attributed to inadequate workshop facilities. Furthermore, technical students' negative attitudes negatively influence students' acquisition of Electrical Installation and Maintenance Work skills. In other words, lack of acquisition of Electrical Installation and Maintenance Work Skills in Technical colleges in Akwa Ibom State is traceable to a large extent, students' negative attitudes before, during and after their training period. Finally, inadequate funding on the other hand, is one of the root causes of most of the Constraints on Acquisition of Electrical Installation and Maintenance Work Skills Among Students in Technical colleges in Akwa-Ibom State.

\section{Recommendations}

From the study, the following recommendations are made below;

(a) special agency for training and retraining of technical teachers (SATRTT), made up of seasoned experts be established to cater for monitoring, training and retraining of technical teachers to keep them continuously ablaze with students' centred teaching methodologies most suitable for technical trades instructions.

(b) Government should establish Agency for Attitudinal Change (AFAC) for technical colleges to take charge of students' performance award, motivation, discipline and encouragement of students in all the technical colleges.

\section{References}

Akaninwor, G. I. K. (2008). Methodology of Technological Instruction. Port Harcourt: Wilson Publishing Co. Ltd.

Ayonmike, C. S. (2014). Training the Trainers in Technical Vocational Education and Training Institutions in Africa: A Tool for Producing Competent Graduates. Journal of Education and Social Science. Resources 2(1), 9-14.

Elias, S. M., Smith, W. L., \& Barney, C. E. (2012).Age as a moderator of attitude towards technology in workplace, work motivation and overall job satisfaction. Behaviour and information technology 31(5), 453-467.

Federal Republic of Nigeria (2004). National Policy on Education (4 ${ }^{\text {th }}$ Edition), Lagos: Nigerian Educational Research Development Commission press.

Idoko, C.U. (2014). Skill Acquisition and Youth Empowerment in Nigeria. Global Journal of Commerce \& Management Perspective, 3(1), 51-54.

Igberadja, S. (2015).Challenges of Implementing Technical and Vocational Education and Training TVET Curriculum in Delta State Colleges of Education. Glo. Advance Resources, Journal of Education Resources Revenue. 4(5), 72-080.

Imogie, I. A. (2014).100 Years of Western Education in Nigeria: The Wobbly Tripod of Growth, Progress and Shortcomings in University Education in the Journey So Far. A Keynote Address Presented At 100 Years Of Nigeria Education: The Journey so far and Prospect For The Future, by Faculty of Education, University of Benin, Benin City, held from $21^{\text {st }}-24^{\text {th }}$ October, 2014. 
National Board for Technical Education (NBTE) (2011). Report of the National Steering Committee on the Development of National Vocational Qualifications Framework $(N V Q F)$ for Nigeria. Retrieved from http://wwwgoogle.com. $11^{\text {th }}$ March, 2013.

National Policy on Education (NPE) (2014). Abuja, Federal Republic of Nigeria. Press.

Ngogo, J. L. (2014). Assessment of Attitudes of Secondary School Students towards Vocational Education and Training in Tanzania: case Study of Mpwapwa District, A Dissertation submitted in partial fulfilment of the requirement for award of degree of Master of Science in Agricultural Education and Extension of Sokoine University of Agriculture. Morogoro, Tanzania.

Ochogba, C.O., Ogide, C.J., \& Ogide, C.G. (2019). Effect of Demonstration Method on Students' Academic Performance in Basic Technology in Secondary Schools in Ogba/ Egbema/Ndoni Local Government Area, Rivers State, Nigeria. International Journal of Innovative Scientific \& Engineering Technologies Research 7(2), 28-32.

Odu, O. K. (2011). Philosophical and Sociological Overview of Vocational and Technical Education in Nigeria. American European Journal of Sciences Resources, 6(1), 52-57.

Ogunniyi, S. O. (2015). Resources utilization, teaching methods' time allocation and attitude as correlates of undergraduates' academic achievement in cataloguing in Library schools in Southern Nigeria. PhD Thesis, Department of Library Archival and Information studies, University of Ibadan, pp155.

Okwelle, P.C., \& Normakoh, J. (2019). Assessment of Health, Safety and Environment Procedures in Technical Colleges' Workshops in Rivers State. International Journal of Innovative Scientific \& Engineering Technologies Research, 7(1), 1-6.

Okwelle, P. C. \& Agwi V. A. (2018). Vocational Teachers' Perception of Assessment in Technical Colleges in Rivers State. International Journal of Education and Evaluation 4(1).

Okwelle, P. C. (2011). Development and Validation of Instrument for Assessing Practical Skills in Radio and Television Systems in Technical Colleges. Unpublished Doctoral Dissertation, NnamdiAzikiwe University, Awka, Anambra State, Nigeria.

Okwelle, P. C., \& Tambari, M.D. (2018). Technical vocational education and training as a tool for sustainable empowerment of youths in Niger Delta, Nigeria. International Journal of Innovative, Social and Science Education Research. 5(1), 29-38.

Puyate, S. T. (2012). Survey of Vocational Education Facilities in Government Technical Colleges in Rivers State. Journal of Nigeria Association of Teachers of Technology (JONATT) 4(1), 175-181.

Puyate, S. T. (2008). Constraints to the Effective Implementation of Vocational Education Programme in Private Secondary Schools in Port Harcourt Local Government Area. Asi Pac. Journal of Corporation Education, 9(1), 59-71.

Puyate, S. T. (2018).Manpower development through relevant technology education curriculum of sustainable poverty alleviation. American Journal of Economics and Business Management 1(1), 54-59. 